\title{
PŘÍSPĚVEK K POZNÁNÍ POLNÍCH OPEVŇOVACÍCH OBJEKTŮ Z ROKU 1968 NA CHRUDIMSKU
}

\author{
JAN MUSIL - PETR NETOLICKÝ
}

\begin{abstract}
Abstrakt: $V$ předloženém př́spěvku prezentujeme výsledky nedestruktivního archeologického výzkumu zaměreného na poznání zachovaného systému polních opevnění v lesích u obce Majlant (k. ú. Dachov) na Chrudimsku. Z analýzy dochovaných vojenských okopů, výsledků dendrochronologického pri̊zkumu a studia historických podkladů vyplývá, že objekty lze datovat do obdobi invaze vojsk států Varšavské smlouvy v srpnu roku 1968.
\end{abstract}

Klíčová slova: modernita - archeologie konfliktu-povrchový průzkum-vojenské okopy - 1968.

\section{A Contribution to Information about Field Fortification Features from 1968 in the Chrudim Region}

Abstract: This article presents the results of non-destructive archaeological research into a preserved system of field fortifications in the woods near the village of Majlant (Dachov cadastral zone) in the Chrudim region. The analysis of military trenches, results of dendrochronological research and study of historical sources show that the features can be dated to the period of the invasion of the Warsaw Pact armies in August 1968 .

Key words: modernity - archaeology of military conflicts - surface prospecting - military trenches - 1968.

\section{1 Úvod}

Členitost a rozmanitost terénu v jižní části okresu Chrudim (východní Čechy, Pardubický kraj) neumožnila do dnešních dnů plně rozvinout zemědělskou činnost, proto je v tomto regionu relativně dominantní lesní hospodářství. Poměrně husté zalesnění sledované oblasti zakonzervovalo př́mo v terénu řadu antropogenních reliktů po sídlištních, výrobních a těžebních aktivitách od středověku po nedávnou minulost. Specifické místo zaujímají velmi rychle zanikající objekty z nedávné minulosti, kterým není z hlediska památkové ochrany věnována téměř žádná pozornost. Č́st těchto objektů je zkoumána v rámci archeologie modernity (Vařeka ed. 2013), popřípadě spadá do oblasti zájmu atraktivnější dynamicky se rozvíjející archeologie konfliktu (Morris 2003; Schofield 2003; 2005; shrnutí pro české země-Rak 2013). Souvislý geodeticko-topografický průzkum železnohorské oblasti nebyl doposud učiněn vzhledem ke značnému plošnému rozsahu území. Od roku 2008 se výzkumu oblasti systematicky věnuje Regionální muzeum v Chrudimi ve spolupráci s Katedrou archeologie Západočeské univerzity v Plzni. Výzkum se dotkl i řady relativně mladých objektů, jakými jsou například c. a k. vojenská střelnice, partyzánské zemljanky ze závěru druhé světové války (Musil-Netolický-Vařeka 2016) či okopy raketového vojska z období tzv. studené války (Musil-Netolický 2014, obr. 5). Nejmladší, ale současně nejdynamičtěji a nejkomplexněji uchopené téma $\mathrm{v}$ rámci průniku humanitních oborů $\mathrm{z}$ historie naší země je studium období totalitních režimů. Jedno z významných a mainstreamových témat nově zformované subdisciplíny archeologie modernity je tak i studium pozůstatků válečných konfliktů. V případě období mezi lety 1948-1989 se nejednalo o ryze válečný konflikt, ale o období tzv. studené války. Nicméně tato podivná válka zanechala po sobě relikty, které byly součástí rozsáhlých, často nepř́stupných vojenských areálů, patrné v podobě vojenských výcvikových prostorů (vojenských hvozdů), základen, letištních a raketových komplexů. Jednoznačně nejvíce a nejlépe zkoumané jsou vojenské objekty na české západní hranici. Toto hraniční pásmo sahalo až několik kilometrů do vnitrozemí a tvořilo bezesporu nejrozporuplnější vojenskou „obrannou“ linii v našich dějinách. Stalo se tak součástí tzv. železné opony, oddělující východní politický blok od západního (k archeologickému průzkumu pohraničního pásma srov. Rak-Starková-Funk 2014, 42-61). Poněkud stranou zájmu zůstávají pozůstatky zanechané po celém našem území po srpnovém vpádu okupačních vojsk států Varšavské smlouvy. Tyto zejména polní opevňovací prvky na rozdíl od pozůstatků železné opony patřily $\mathrm{k}$ více diverzifikovaným vojenským objektům. 
V předloženém příspěvku prezentujeme výsledky nedestruktivního archeologického výzkumu zaměřeného na poznání zachovaného systému polních opevnění v lesích u obce Majlant (k. ú. Dachov) na Chrudimsku z období vpádu vojsk Varšavské smlouvy, tj. srpna až prosince roku 1968.

\section{Historický rámec a svědectví místních kronik}

Problematice obsazení Československa vojsky armád pěti států Varšavské smlouvy a událostem, které tomu bezprostředně předcházely, byla již dříve věnována řada publikací (z velkého výběru domácí produkce napřr. Benčík 1994; 1998; Benčík-Navrátil-Paulík 1996; Blažek ed. 2006; Durman 1998; Emmert 2007; Havlíček 1998; Horák-Novotník 2004; Chrastil-Novotník 2002; Pauer 2004; Pazderka ed. 2011; Pecka et al. 1996; prŕímo pro východočeský prostor - Herold-Lenderová-Svatoňová-Zimmermann 1990; Kobetič 1990; Kinzlová 2012; ze zahraničních prací např. Феськов-Калашников-Голиков 2004; Kurlansky 2007; Маиоров 1998; Pajórek 1998; Wenzke 1995; Williams 1997). Pro naše účely jsou zásadní monografie D. Povolného (2008; 2010), které mapují nejen průběh vlastní invaze, ale také přecházející vývoj a zákulisí událostí let 1967-1968.

Můžeme říci, že politická situace se od roku 1967 pro tehdejší Československou socialistickou republiku (dále ČSSR) nevyvíjela př́iliš slibně. Praktické zahájení př́íprav na invazi do ČSSR počalo již v březnu 1968, kdy bylo zahájeno plánování operace s krycím názvem DUNAJ. V rámci utajení byla označována jako vojenské cvičení armád států Varšavské smlouvy (Povolný 2008, 21-22). První pokus o vstup vojsk Varšavské smlouvy se uskutečnil již v květnu roku 1968 (Povolný 2008, 28-30), další představovalo vojenské cviční ŠUMAVA v květnu až červnu roku 1968 (Povolný 2008, 31-54). Cílem bylo rekognoskovat terén, vytipovat důležitá místa, vhodně rozmístit vlastní jednotky a případně eliminovat odpor Československé lidové armády (dále ČSLA). Po ukončení cvičení se z území ČSSR rychle stáhly jednotky Mad’arské lidové armády, pomalu a váhavě se stahovaly oddíly Národní lidové armády NDR, Polské lidové armády a sovětské armády (Povolný 2008, 72). Vojenské jednotky výše zmíněných armád doplněné o kontingenty Bulharské lidové armády byly v průběhu července a srpna 1968 pod záminkou dalších vojenských cvičení dislokovány v blízkém i vzdáleném okolí ČSSR (např. cvičení POCHMURNE ŁATO 68 - Pajórek 1996, 69-70; SEVER - Pajórek 1998, 56; Маиоров 1998, 215; NEBESKÝ ŠTÍT - Pajórek 1998, 56; NĚMEN - Pajórek 1998, 57).

Vlastní invazi dne 20. srpna 1968 ve 22:15 středoevropského času zahájil kódový signál VLTAVA - 666. Na území Československa vstoupily jednotky SA, MLA, PLA, NLA a BLA po předchozím týlovém zabezpečení (Povolný 2008, 97-104). Východní Čechy měla za úkol obsadit 10. a 11. tanková divize 2. armády PLA, přičemž nerušený vstup na naše území jí zajištoval diverzní a průzkumný 1 . samostatný úderný prapor podplukovníka T. Wandzela ve spolupráci s polskými pohraničníky, zejména z 5. sudetské brigády WOP (Povolný 2008, 98, 116). Do 23:00 se 11. tanková divize PLA přemístila z výchozího prostoru Chojnów-Złotoryja-Jawór do dvou nástupních prostorů: 1. Łubawka (Złotoryja-Kamiena Góra) a 2. Mieroszów (Jawór-Świebodzice). Z nástupního prostoru Mieroszów pak směřovaly polské jednotky do východních Čech v trase Hronov-Náchod-Česká Skalice-Hradec Králové-Pardubice. Postupující jednotky měly v Přelouči, Jaroměři, Hradci Králové a Pardubicích vytvořit vojenská velitelství (Pajórek 1998, 134; Povolný 2008, 116). Leteckou podporu pro pozemní jednotky zajištovalo 13 průzkumných proudových letounů Lim-2R ${ }^{1}$ a zhruba dvacet vrtulníků typů Mi-2, Mi-4 a Mi-8T. Desátá tanková divize PLA se přemístila z výchozího prostoru Opołe-Niemodłin-Biała-Krupkowice do dvou nástupních prostorů: 1. Pietrowice (Biała-Głubczyce) a 2. Płisz (Głogówek-Baborów). Z nástupního prostoru Pietrowice postupovaly jednotky PLA v trase Krnov-Bruntál-RýmařovŠumperk-Lanškroun-Litomyšl-Chrudim s bočními osami postupu na Ústí nad Orlicí a Žamberk a Holice s velitelstvími v Šumperku a Ústí nad Orlicí. Z nástupního prostoru Płisz polské

1 V Polsku licenčně vyráběná kopie sovětského stíhacího letounu MiG 15 bis. 
jednotky postupovaly v trase Opava-Šternberk-Mohelnice-Svitavy-Polička-Hlinsko-Havlíčkův Brod s boční osou postupu na Bystřici nad Pernštejnem, Žd’ár nad Sázavou a Golčův Jeníkov s vojenskými velitelstvími ve Svitavách, Bystřici nad Pernštejnem, Hlinsku, Žd’áru nad Sázavou a Havličckově Brodě (Pajórek 1998, 134; Povolný 2008, 119). Do večerních hodin 21. 8. 1968 bylo v ČSSR soustředěno 12846 vojáků, 456 tanků, 320 obrněných transportérů, 178 děl, 2564 aut a šest letadel, tj. dvě tankové divize, jeden motostřelecký pluk, část 2. armády a její předsunuté velitelské stanoviště PLA (Pajórek 1996, 77; Povolný 2008, 120). Ke dni 25. 8. 1968 byly počty polských jednotek navýšeny na 24341 vojáků, 647 tanků, 588 obrněných transportérů, 393 děl, 4799 automobilů a 26 letadel (Pajórek 1996, 77-81; 1998, 157-161; Povolný 2008, 133). Ke dni 14. 9.1968 vzrostl vojenský kontingent PLA na 28612 vojáků, 750 tanků, 592 obrněných transportérů, 434 děl, 5663 automobilů a 36 letadel (k počtům a struktuře kontingentu PLA srov. Povolný 2010, 156-157).

\subsection{Svědectví obecních kronik}

Obecní kroniky představují alespoň pro Chrudimsko jeden z nejdůležitějších dostupných pramenů dokumentujících přítomnost polních opevnění z doby srpnové invaze do Československa. Zápisy z roku 1968 se v podstatě dělí na dvě hlavní skupiny. První skupinu tvoří politicky neutrální zápisy, konstatující přítomnost vojsk Varšavské smlouvy bez bližších vysvětlujících údajů. Druhou skupinu představují detailní zápisy dokumentující zejména období 21.-30. 8. 1968. I když se z důvodů vojenského tajemství nedozvídáme z kronik jména velících důstojníků či podrobnosti o názvech a typech konkrétních vojenských jednotek, umožňují kronikářské zápisy zpřesnit často velmi různorodé a zavádějící informace pamětníků, jak co do situování ležení (obr. 1), tak i co do odhadu přibližné velikosti vojenských jednotek.

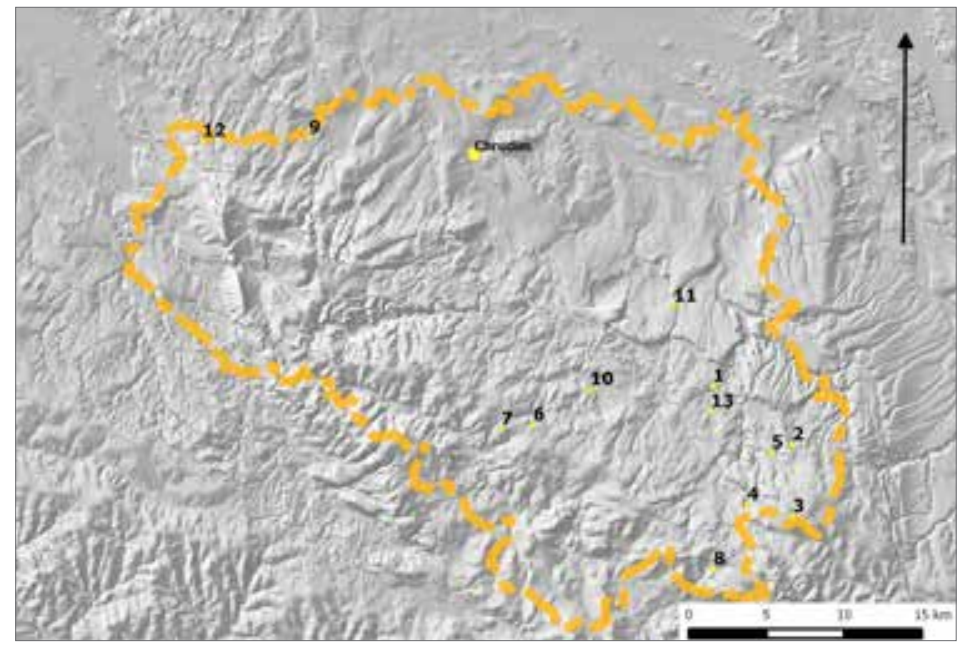

Obr. 1. Lokalizace známých ležení invazních vojsk na území okresu Chrudim. 1 - Předhradí, 2 - Proseč u Skutče, 3 - Františky, 4 - Rychnov, 5 - Česká Rybná, 6 - lesní komplex mezi obcemi Srní - Včelákov, 7 - Petrkov, 8 - Svratouch, 9 - Heřmanův Městec, 10 - Tisovec, 11 - Hroubovice, 12 - Nový Dvůr u Podhořan u Ronova n. D., 13 - Lešany, 14 - Majlant - Dachovské Paseky. Vytvořeno v programu QGIS na podkladu DMR 4G. Zdroj ČÚZK.

Abb. 1. Lokalisierung der bekannten Lager der Invasionsarmeen auf dem Gebiet des Bezirks Chrudim. 1 - Předhradí/Richenburg, 2 - Proseč u Skutče/Prosetsch bei Skutsch, 3 - Františky/ Franzensdorf, 4 - Rychnov/Reichenau, 5 - Česká Rybná/Böhmisch Rybna, 6 - Waldkomplex zwischen den Gemeinden Srní/Rehfeld und Včelákov/Tschelakow, 7 - Petrkov, 8 - Svratouch/ Swratauch, 9 - Heřmanův Městec/Hermannstädtel, 10 - Tisovec, 11 -Hroubovice/Raubowitz, 12 - Nový Dvůr u Podhořany u Ronova nad Dobravou/Neuhof bei Podhorschan bei Ronow an der Doubrawa, 13 - Lešany/Leschan, 14 - Majlant - Dachovské Paseky/Dachauer Lichtungen. Erstellt mit der Software QGIS nach Vorlage des DMR 4G (Digitales Reliefmodell der Tschechischen Republik 4. Generation). Quelle Tschechisches Amt für Vermessung und Kataster. 
Detailní popis poskytla i kronika města Chrasti (Kronika 1966-1982, 64-67). Podle zápisu kolem 18. hodiny dne 22. 8. 1968 byl směrem od Podlažic slyšet hluk tankových motorů. Jednalo se o polské jednotky postupující od Nových Hradů přes Luži a Dobrkov do Podlažic, odkud po skutečské silnici směřovaly na Chacholice, Skálu, Vrbatův Kostelec do Skutče (viz níže). Dne 24. 8. 1968 kolem 18. hodiny projelo Chrastí pět aut PLA a nad městem několikrát přeletěl vrtulník. V následujících dnech městem projely pouze dva cisternové vozy PLA (zmiňovány i skutečskou kronikou - viz níže) a dne 30. 8. 1968 se ve městě objevil agitační polský automobil rozhazující letáky. Tyto informace doplňuje a zpřesňuje i skutečská kronika (Pamětní kniha města Skutče 1967-1970, 69-72). Dne 21. 8. 1968 mezi 17. a 18. hodinou projelo Skutčí asi 40 vozidel PLA směrem Luže-Hroubovice-Podlažice-Vrbatův Kostelec-Cejřov-Včelákov, mezi 21. a 23. hodinou projelo asi 140 vozidel stejným směrem. Později jelo asi 90 automobilů PLA směrem od Cejřova ke Včelákovu. Dne 22. 8. 1968 projelo 13 vozidel PLA Prosetínem a Mrákotínem. Dne 25. 8.1968 kronika eviduje častější přelety vrtulníků a o den později průjezd dvou cisternových vozidel PLA. V ranních hodinách dne 27. 8. 1968 směrem od Přibylova přijely tři polské agitační vozy, z nichž byly rozhazovány letáky s českým textem. Navečer městem dvakrát projel lehký nákladní automobil Garant PLA. Následujícího dne (tj. 28. 8.) se na posekané louce u obce Předhradí utábořila jednotka dělostřelců PLA v počtu 500-600 mužůn, nad Skutčí prolétaly vrtulníky shazující agitační letáky. Př́íslušníci PLA zastavovali auta, z nichž odstraňovali transparenty a vlaječky, které nahrazovali svými plakáty. V samotném městě pak po 22 . hodině př́islušníci PLA vylepovali plakáty, které místní obyvatelé ihned strhli. Následujícího dne byl popsán vzorový př́íklad pasivního domácího odporu. Ve čtvrtek ráno se pokoušel vůz PLA najít cestu na místní služebnu SNB, ovšem vzhledem k tomu, že orientační tabule byly již dř́ve odstraněny, podařilo se jim to až po delším bloudění. Na služebně SNB si polští vojáci výslovně stěžovali na přístup místních občanů, kteří strhali polské plakáty vylepené navečer předchozího dne. Dle zápisu kroniky: „Dostali radu, aby si své plakáty vylepovali v Polsku.“ Rovněž byla zamítnuta žádost o poskytnutí pitné vody a př́stup na letiště s odůvodněním, že vody je nedostatek a letiště je státním, nikoliv obecním majetkem. Ještě téhož odpoledne se najednou na letišti objevily kupky sena a pásly se tam krávy. Polští vojáci byli nuceni umývat se a prát si své prádlo u rybníka Spálivec v Předhradí a pitnou vodu přivážet od studánky u Lešan (Pamětní kniha města Skutče 1967-1970, 69-72).

Podobně sdílná je i kronika města Proseče (Kronika obce Proseče 1968, 146-147), která popisuje nejen příchod okupantů, ale také datum jejich stažení. Patrně nejdůležitější informaci přinesla kronika o zřízení dělostřeleckého postavení PLA v poloze Jonášův kopec dne 26. 8. 1968. Baterie o čtyřech dělech, 15 automobilech a 50 vojácích byla k všeobecnému znepokojení zdejších obyvatel zamířena prímo na město. Dělostřelecké postavení zde zůstalo aktivní až do 23. 10. 1968, kdy se PLA v dopoledních hodinách stáhla. Pramen dále uvádí vojenská ležení PLA v lesích na katastrech obcí Františky, Rychnov a Česká Rybná (viz níže), odkud se polské jednotky začaly stahovat $\mathrm{v}$ sobotu 26. 10. 1968. Hlinecká kronika zmiňuje polskou jednotku dislokovanou v lesích podél silnice mezi Srním a Včelákovem. Velitel polské jednotky požadoval 24. 8. 1968 na MěNV kancelář a prostory pro zřízení velitelství, ale 30. 8. 1968 od záměru upustil a klíče od místnosti vrátil (Kronika města Hlinska 1968, 82).

Další informace nalezneme v kronice nedaleké obce Ctětína. Obcí dne 24. 8. 1968 projely dva automobily PLA přes Vranov k Petrkovu, kde se nalézalo ležení (Kobetič 1990, 4). Lokalizaci některých ležení PLA zpřesňuje i kronika obce Krouna. V zápisu ke dni 25. 8. 1968 je uvedeno: „Po silnicích hlídkují v ,gazikách ' polští vojáci. Mají rozhlasová zařizení. Svými relacemi informuji obyvatelstvo o kontrarevoluci. Na př́kaz polského velitelstvi stáhli se vojáci z obcí a utábořili se v polich a lesích. Velký tábor byl mezi Rychnovem a Českou Rybnou v, Rybenských Hatinách: Byli též v Kablaních. Druhý tábor byl u Lešan, nedaleko Předhradí. V tento den létaly helikoptéry nad naši obcí a rozhazovaly letáky“ (citováno podle Kobetič 1990, 10). Další průjezd polského rozhlasového vozu kronika uvádí 31. 8. 1968 (Kobetič 1990, 13). Poslední zmínka o existenci tábořiště PLA přináší kronika obce Svratouch. Výslovně se v ní zmiňuje přítomnost 
PLA v lesích, dne 24. 8. projely obcí dva obrněné vozy a dne 25. 8. jeden GAZ (Kobetič 1990, 16).

Svědectví obecních a městských kronik doplňují i vzpomínky pamětníků. Např́íklad díky informacím Ing. Slavomíra Kudláčka se podařilo v terénu lokalizovat vojenská ležení u Hroubovic a Tisovce, kterým bude věnována náležitá pozornost v př́štích letech. V severní části Chrudimska, kde takřka chybí souvislejší plochy lesa, vznikala vojenská ležení přímo na loukách podél silnic. Poměrně plasticky to dokumentuje kronika města Heřmanova Městce. První menší polské vojenské kontingenty projely městem 23. 8. 1968, v poledne projely městem tři tanky od Čáslavi k Chrudimi (Kobetič 1990, 5). Ke dni 25. 8. 1968 přináší městská kronika následující informaci: „V 14 hodin projela městem lod Chrudimě k Čáslavi/ velká skupina polských tankủ a doprovodných vozů v bojové pohotovosti. (...) Kolona se usadila západnè od města na silnici ke Stojicům, která se tak stala neprůjezdnou. (...) Jednotlivé tanky a vozy dojižděly za odpolední kolonou až do večera." Takto vzniklo vojenské ležení v trati V Důlní (Kobetič 1990, 6). Teprve 7. 9. 1968 polské jednotky uvolnily cestu do Stojic a přestěhovaly se na letiště u Nového Dvora u Podhořan (Kobetič 1990, 7).

3 Příkladová studie - ležení PLA v lesní trati U Salvátora, místní části Dachovské Paseky Majlant, k. ú. Dachov (obr. 2)

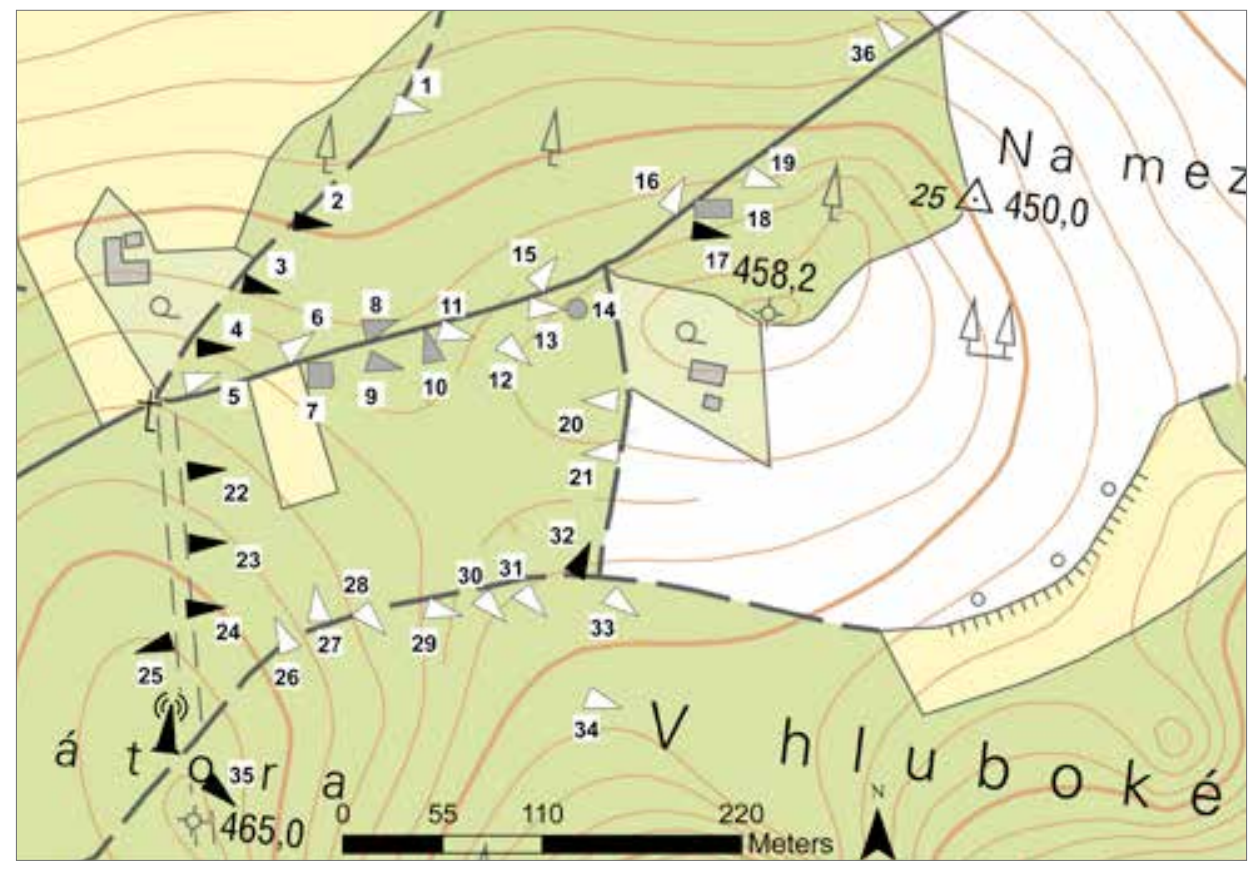

Obr. 2. Dachovské Paseky - Majlant, k. ú. Dachov, okr. Chrudim. Schematické znázornění a rozmístění vojenských objektů. Půdorysný plán. Černý trojúhelník - okop pro tank; bílý trojúhelník - okop pro OT; šedý trojúhelník - okop pro kulomet (hroty trojúhelníků označují čelní směr); čtverec - okop pro tarasnici/RPG; obdélník - okop pro ležícího střelce; kolečko - blíže nezařaditelný vojenský okop. Vytvořeno v programu ArcMap10 na podkladu Základní mapy ČR 1:10 000 Zdroj ČÚZK.

Abb. 2. Dachovské Paseky/Dachauer Lichtungen - Majlant, Katastergebiet.Dachov/Dachau, Bezirk Chrudim. Schematische Darstellung und Verteilung der Militärobjekte. Grundrissplanskizze. Schwarze Dreiecke - Schützengräben für Panzer; weiße Dreiecke - Schützengräben für gepanzerten Transporter; graue Dreiecke - Schützengräben für Maschinengewehre (die Dreieckspitzen zeigen die Schussrichtung an); Quadrat - Schützengraben für Panzerfaust RPG; Rechtecke - Schützengräben für liegende Schützen; Kreis - Schützengraben, der nicht näher zugeordnet werden kann. Erstellt mit der Software ArcMap10 nach Vorlage der Grundkarte Tschechiens 1:10 000. Quelle Tschechisches Amt für Vermessung und Kataster. 
Při povrchovém průzkumu reliktů zaniklého středověkého osídlení u obce Majlant nad místní částí Dachovské Paseky (vše k. ú. Dachov) jsme měli možnost dokumentovat relikty vojenských okopů pro těžkou techniku (tanky T-54² a obrněné kolové transportéry typů BRMD-1, ${ }^{3}$ BRDM-2 ${ }^{4}$ BMP- $1,{ }^{5}$ SKOT, ${ }^{6}$ D-442 FÚG ${ }^{7}$ či pásové transportéry typů BTR-50 ${ }^{8}$ ) a pěchotu, které byly provedeny dle vojenské doktríny vojsk Varšavské smlouvy ${ }^{9}$ (srov. ŽEN 2-1/1; Linha et al. 1971). Komparací svědectví obecních kronik, místních pamětníků a provedeného dendrochronologického průzkumu (Váňa 2016) bylo zjištěno, že se jedná o pozůstatky ležení menšího vojenského kontingentu PLA ze srpna roku 1968.

\subsection{Metoda studia}

Cílem první etapy, využívající výlučně nedestruktivních metod, bylo testování možností archeologického studia hmotných pozůstatků okupačních vojsk, ověrení podoby a vlastností těchto $\mathrm{v}$ terénu dochovaných objektů a sledování jejich prostorového kontextu na vymezeném polygonu. Typickým reliktem jsou polní opevňovací objekty (nap̌r. okopy pro tanky, obrněná vozidla, kulomety, ležící stř̌elce atd.), které představovaly ženijní prostředek zajišt’ující obranu jednotlivých ležení. Jako reprezentativní vzorek jsme zvolili relativně dobře zachované ležení PLA v zalesněném prostoru nedaleko obce Miřetice na Hlinecku. Relikty polních opevňovacích objektů byly dokumentovány s využitím metod povrchového průzkumu reliéfních antropogenních tvarů a zaměřeny totální měřičskou stanicí, obdobně jako jiné antropogenní objekty zkoumané v lesním prostředí (Vařeka 2009, 57-60). Průzkum sledoval také nejbližší okolí vojenského kontingentu na ploše více než 2 ha, kde byly zachyceny další antropogenní relikty, patrně středověkého a raně novověkého stáří, o kterých bude referováno později. V období vegetačního klidu bylo provedeno geodetické zaměření terénních reliktů pomocí totální měřičské stanice LEICA TS06plus 5" R500. Výsledná data byla zpracována v programu ArcMap10 a připojena k podkladové digitální Základní mapě ČR 1:10 000. Pro sledování prostorového kontextu, reliéfu a dalších antropogenních objektů na území $2,5 \times 2,5$ km využíváme digitální model reliéfu 5 . generace vytvořeného na základě leteckého laserového skenování (DMR5G, Český úřad zeměměřický a katastrální). Data byla zpracována v prostředí GIS s využitím několika vizualizačních metod.

V rámci př́rodovědných analýz proběhl dendrochronologický výzkum stromů rostoucích na zkoumané lokalitě (Váňa 2016). Metoda datace archeologických reliktů pomocí dendrochronologie živých stromů již v minulosti posloužila k dataci zániku staveb v prostředí vesnic opuštěných po roce 1945 (Funk-Váňa 2012). Na zkoumané lokalitě bylo ovzorkováno celkem 14 stromů (letokruhy se podařilo spočítat u 12 vzorků). Dendrochronologické vzorky byly ze stromů odebírány Presslerovým prŕri̊stovým nebozezem od finské firmy Suunto o délce $25 \mathrm{~cm}$. Stromy byly vrtány ve výšce zhruba $150 \mathrm{~cm}$ od povrchu země. K dataci byly vybírány stromy rostoucí na

2 T-54 - střední tank sovětské provenience licenčně vyráběný v zemích bývalého východního bloku. Technicko-taktická data: délka 6,46m, šiřka 3,27 m, výška 2,4 m, hmotnost 36,6t. Výzbroj: kanón ráže $100 \mathrm{~mm}$, kulomet ráže 7,62 mm a velkorážový kulomet ráže $12,7 \mathrm{~mm}$. Osádku tvořili čtyři muži.

3 BRMD-1 - obrněný kolový transportér sovětské provenience. Technicko-taktická data: délka 5,7 m, šírka 2,25 m, výška 2, 9m, hmotnost 5,1 t. Výzbroj: kulomet ráže 7,62 mm, nebo velkorážný kulomet ráže 12,7 mm. Osádku tvořili tři až čtyři muži.

4 BRMD-2 - obrněný kolový transportér sovětské provenience. Technicko-taktická data: délka $5,75 \mathrm{~m}$, šířka 2,35 m, výška 2,31 m, hmotnost 7 t. Výzbroj: kulomet ráže $14,5 \mathrm{~mm}$, kulomet ráže $7,62 \mathrm{~mm}$. Osádku tvořili čtyři muži.

5 BMP-1 - obrněný kolový transportér sovětské provenience licenčně vyráběný v ČSSR pod označením BMP-1. Technicko-taktická data: délka $6,74 \mathrm{~m}$, šírka $2,94 \mathrm{~m}$, výška $2,15 \mathrm{~m}$, hmotnost 12,5 t. Výzbroj: kanón ráže $73 \mathrm{~mm}$, kulomet ráže 7,62 mm, odpalovací zařízení PTŘS Maljutka. Osádku tvořili tři muži, výsadek osm mužů.

6 Obrněný kolový transportér československo-polské provenience SKOT (Średni Kołowy Opancerzony Transporter) v ČSLA pod označením OT-62. Technicko-taktická data: délka 7,44 m, šířka 2,56 m, výška 2,83 m, hmotnost 12,9t. Výzbroj: velkorážný kulomet ráže 14,5 mm spřažený s kulometem ráže $7,62 \mathrm{~mm}$. Osádku tvořili dva muži, výsadek deset mužů.

7 D-442 FÚG - obrněný kolový transportér mad’arské provenience později licenčně vyráběný v ČSSR pod označením OT-64. Technicko-taktická data: délka 5,79 m, šířka 2,5 m, výška 1,91 m, hmotnost 7 t. Výzbroj: kulomet ráže 7,62 mm. Osádku tvořili dva muži, výsadek čtyři muži. 8 BTR-50 - obrněný pásový transportér sovětské provenience, později licenčně vyráběný v ČSSR pod označením OT-65. Technicko-taktická data: délka 7,07 m, šířka 3,14 m, výška 2,03 m, hmotnost 14,5 t. Výzbroj: kulomet ráže 7,62 mm. Osádku tvořili dva muži, výsadek dvacet mužů. 9 Varšavská smlouva, správně Smlouva o přátelství, spolupráci a vzájemné pomoci, představovala protiváhu NATO. Podepsána byla v roce 1955. Pro vojenské kruhy znamenala zejména unifikaci výzbroje (zejm. munice). Stavba polních opevňovacích systémů je tedy prakticky shodná ve všech zemích někdejšího východního bloku (srov. nap̌r. sovětské příručky - Руководство 1962; Сборник 1970; КалиберновКорнев-Сосков 1984). 


\begin{tabular}{|c|c|c|c|c|c|c|}
\hline Objekt & Interpretace & $\begin{array}{c}\text { Délka } \\
\text { max./min. v m }\end{array}$ & $\begin{array}{c}\text { Šířka } \\
\text { max./min. v m }\end{array}$ & $\begin{array}{l}\text { Max. hloub- } \\
\text { ka v m }\end{array}$ & Stav & $\begin{array}{l}\text { Rok vykliče- } \\
\text { ní stromu }\end{array}$ \\
\hline 1 & okop pro obrněný transportér & $5,4 / 3,1$ & $3,5 / 2,6$ & 0,2 & porušený & $\mathrm{xx}$ \\
\hline 2 & okop pro tank ve věžovém postavení & $9,5 / 7,0$ & $4,0 / 2,9$ & 0,4 & dobrý & $\mathrm{xx}$ \\
\hline 3 & okop pro tank ve věžovém postavení & $8,4 / 7,4$ & $3,8 / 2,9$ & 0,6 & velmi dobrý & 1969 \\
\hline 4 & okop pro tank ve věžovém postavení & $8,5 / 7,2$ & $5,3 / 4,0$ & 0,7 & velmi dobrý & $\mathrm{xx}$ \\
\hline 5 & okop pro obrněný transportér & $7,8 / 6,5$ & $5,1 / 3,7$ & 0,4 & dobrý & $\mathrm{xx}$ \\
\hline 6 & okop pro obrněný transportér & $6,2 / 4,2$ & $4,4 / 3,3$ & 0,4 & dobrý & 1980 \\
\hline 7 & okop pro střelce $\mathrm{z}$ tarasnice & $\mathrm{xx} / 4,6$ & $4,2 / x x$ & 0,5 & velmi dobrý & 1973 \\
\hline 8 & okop pro kulomet & $5,2 / 3,6$ & $1,5 / 0,7$ & 0,5 & velmi dobrý & 1973 \\
\hline 9 & okop pro kulomet & $5,5 / 4,1$ & $1,7 / 0,6$ & 0,6 & velmi dobrý & $\mathrm{xx}$ \\
\hline 10 & okop pro kulomet & $5,4 / 3,8$ & $1,8 / 0,9$ & $\mathrm{xx}$ & velmi dobrý & $\mathrm{xx}$ \\
\hline 11 & okop pro obrněný transportér & $\mathrm{xx} / 4,4$ & $\mathrm{xx} / 2,7$ & $\mathrm{xx}$ & porušený & $\mathrm{xx}$ \\
\hline 12 & okop pro obrněný transportér & $6,6 / 5,7$ & $5,5 / 4,4$ & 0,7 & velmi dobrý & 1985 \\
\hline 13 & okop pro obrněný transportér & $6,1 / 5,4$ & $5,8 / 5,0$ & 0,4 & dobrý & 1980 \\
\hline 14 & vojenský okop & $\mathrm{xx} / \mathrm{xx}$ & $5,3 / x x$ & 0,6 & porušený & $\mathrm{xx}$ \\
\hline 15 & okop pro obrněný transportér & $\mathrm{xx} / 6,7$ & $\mathrm{xx} / \mathrm{xx}$ & $\mathrm{xx}$ & velmi špatný & 1969 \\
\hline 16 & okop pro obrněný transportér & $5,8 / 5,4$ & $4,6 / 3,5$ & 0,6 & porušený & $\mathrm{xx}$ \\
\hline 17 & okop pro tank ve věžovém postavení & $7,7 / 5,6$ & $6,6 / 5,0$ & 0,6 & velmi dobrý & $\mathrm{xx}$ \\
\hline 18 & okop pro ležícího střelce & $3,0 / x x$ & $1,0 / x x$ & 0,3 & velmi špatný & $\mathrm{xx}$ \\
\hline 19 & okop pro obrněný transportér & $6,0 / 5,0$ & $5,3 / 3,7$ & $\mathrm{xx}$ & velmi špatný & $\mathrm{xx}$ \\
\hline 20 & okop pro obrněný transportér & $7,4 / x x$ & $\mathrm{xx} / \mathrm{xx}$ & $\mathrm{xx}$ & velmi špatný & $\mathrm{xx}$ \\
\hline 21 & okop pro obrněný transportér & $6,3 / 5,2$ & $\mathrm{xx} / \mathrm{xx}$ & $\mathrm{xx}$ & velmi špatný & $\mathrm{xx}$ \\
\hline 22 & okop pro tank ve věžovém postavení & $\mathrm{xx} / \mathrm{xx}$ & $\mathrm{xx} / \mathrm{xx}$ & $\mathrm{xx}$ & velmi špatný & $\mathrm{xx}$ \\
\hline 23 & okop pro tank ve věžovém postavení & $\mathrm{xx} / \mathrm{xx}$ & $\mathrm{xx} / \mathrm{xx}$ & $\mathrm{xx}$ & velmi špatný & $\mathrm{xx}$ \\
\hline 24 & okop pro tank ve věžovém postavení & $6,6 / 5,8$ & $4,6 / 3,6$ & 0,4 & dobrý & 1978 \\
\hline 25 & okop pro tank ve věžovém postavení & $9,0 / 8,4$ & $4,7 / 3,3$ & 0,9 & dobrý & $\mathrm{xx}$ \\
\hline 26 & okop pro obrněný transportér & $6,3 / 5,8$ & $5,9 / 4,5$ & 0,9 & velmi dobrý & $\mathrm{xx}$ \\
\hline 27 & okop pro obrněný transportér & $7,4 / 6,8$ & $5,5 / 3,6$ & 1,0 & velmi dobrý & $\mathrm{xx}$ \\
\hline 28 & okop pro obrněný transportér & $8,3 / 7,7$ & $5,7 / 4,4$ & 1,0 & dobrý & $\mathrm{xx}$ \\
\hline 29 & okop pro obrněný transportér & $6,7 / 5,9$ & $5,3 / 4,0$ & 0,7 & dobrý & $\mathrm{xx}$ \\
\hline 30 & okop pro obrněný transportér & $6,1 / 5,5$ & $5,3 / 4,4$ & 0,7 & dobrý & $\mathrm{xx}$ \\
\hline 31 & okop pro obrněný transportér & $4,8 / 4,4$ & $5,5 / 4,1$ & 0,5 & dobrý & $\mathrm{xx}$ \\
\hline 32 & okop pro tank ve věžovém postavení & $7,7 / x x$ & $\mathrm{xx} / 5,0$ & 0,7 & porušený & $\mathrm{xx}$ \\
\hline 33 & okop pro obrněný transportér & $5,3 / 4,2$ & $5,1 / 4,2$ & 0,4 & dobrý & $\mathrm{xx}$ \\
\hline 34 & okop pro obrněný transportér & $5,6 / 5,2$ & $5,9 / 5,1$ & 0,3 & velmi dobrý & $\mathrm{xx}$ \\
\hline 35 & okop pro tank ve věžovém postavení & $\mathrm{xx} / \mathrm{xx}$ & $\mathrm{xx} / \mathrm{xx}$ & 0,3 & porušený & 1935 \\
\hline 36 & okop pro obrněný transportér & $6,0 / 5,1$ & $4,6 / 3,0$ & $\mathrm{xx}$ & porušený & $\mathrm{xx}$ \\
\hline
\end{tabular}

Tab. 1. Dachovské Paseky - Majlant, k. ú. Dachov, okr. Chrudim. Základní deskripce vojenských objektů.

Tab. 1 - Dachovské Paseky/Dachauer Lichtungen - Majlant, Katastergebiet Dachov/Dachau, Bezirk Chrudim. Allgemeine Beschreibung der Militärobjekte.

objektech nebo v jejich bezprostřední blízkosti na místech, kde by za běžných okolností bránily původní funkci objektu (nap̌r. uprostřed vjezdu do okopu nebo v místech zakrývajících výhled na komunikaci). Dendrochronologické vzorky tak určily nejstarší stromy u celkem u devíti objektů (viz tab. 1). Jedinou výjimku představuje strom v př́ípadě obj. 35, jenž na této lokalitě začal růst již v roce 1935, který nijak nevadil funkci okopu a mohl se zde nacházet již v průběhu ženijních prací. 

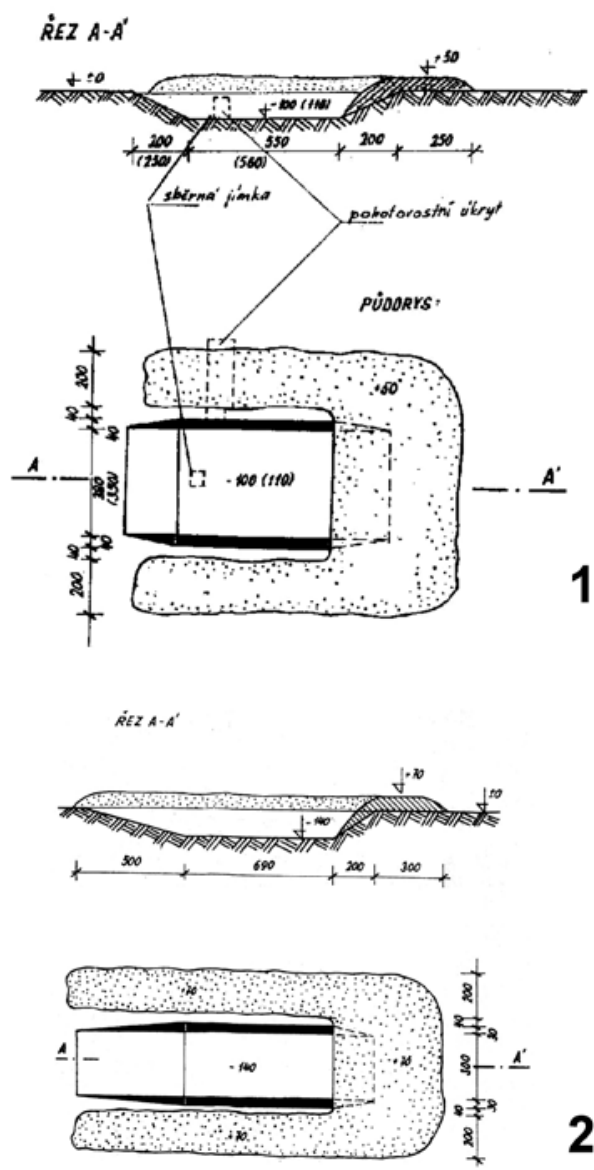

Obr. 3. Vzorové plány okopů podle předpisu Žen 2-1/1. 1 okop pro tanky typů T-54 a T-55; 2 - okop pro OT SKOT. Abb. 3. Musterplanskizze für Schützengräben gemäß der Vorschrift Žen 2-1/1. 1 - Schützengraben für Panzer vom Typ T-54 und T-55; 2 - Schützengraben für gepanzerte Transporter SKOT.

telná vnější a vnitřní hrana koruny okopu), 5 - současná hloubka od koruny okopu v metrech, 6 - současný stav, 7 - rok vyklíčení stromu (podle Váňa 2016).

\subsubsection{Okopy pro tanky}

Nejmohutnější a nejlépe rozeznatelné antropogenní relikty představují okopy pro tanky ve věžovém postavení. Dle tehdejších vojenských předpisů shodných pro celé uskupení států Varšavské smlouvy měly být tyto okopy hloubeny pomocí techniky či trhavin, pouze výjimečně ručně. Okopy musely zabezpečovat dobré podmínky pro vedení palby, ochranu osádek a zčásti i vozidel před nepřátelskou palbou. Vojenská doktrína rozeznávala tzv. částečně zapuštěný okop $^{10}$ a okop pro tank ve věžovém postavení. Vlastní okop sestával z palebné pláně a násypů. Tank měl z tohoto postavení zabezpečen kruhový výstřel. Rozměry okopu byly stanoveny tak, že spodní šiřka okopu se rovnala širrce vozidla zvětšené o $0,5 \mathrm{~m}$, spodní délka okopu se rovnala

10 De facto první etapa budování okopu. 


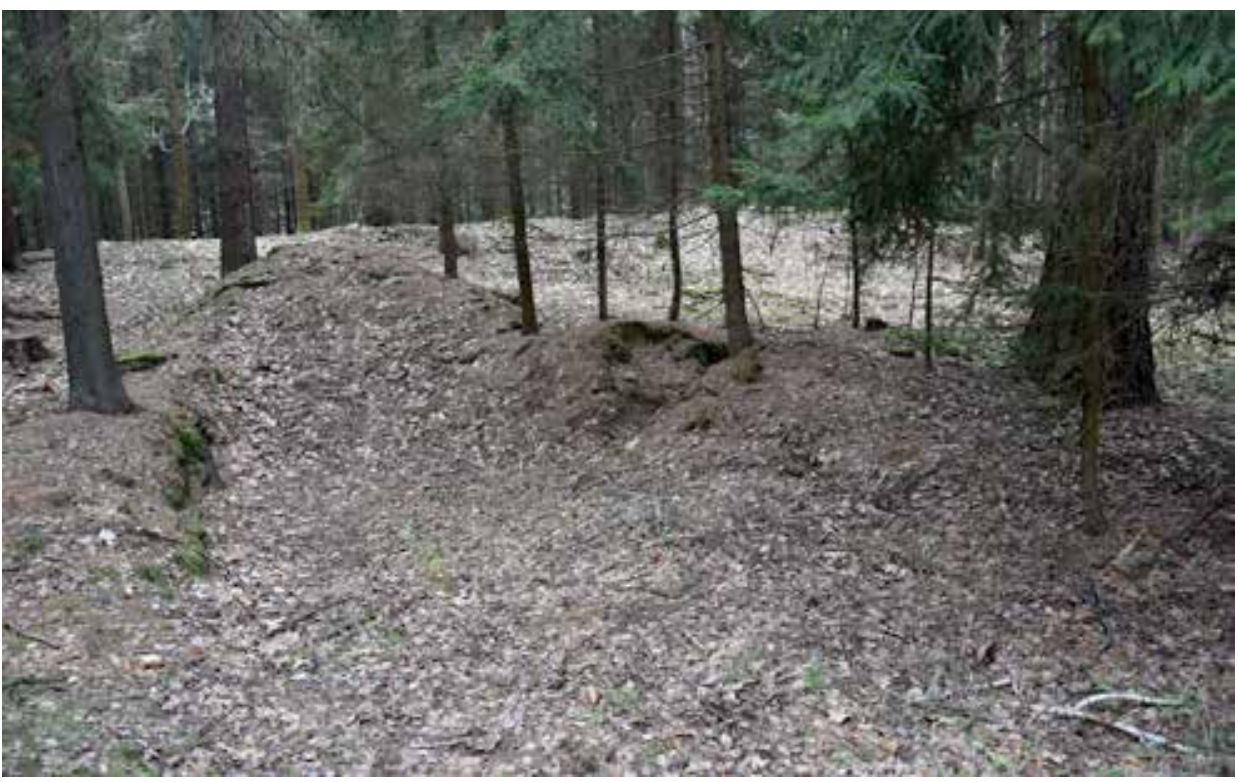

Obr. 4. Dachovské Paseky - Majlant, k. ú. Dachov, okr. Chrudim. Obj. 25 - okop pro tank ve věžovém postavení. Vpravo je patrný výklenek po propadlém pohotovostním krytu. Pohled od východu. Foto J. Musil.

Abb. 4. Dachovské Paseky/Dachauer Lichtungen - Majlant, Katastergebiet Dachov/Dachau, Bezirk Chrudim. Objekt 25 Schützengraben für einen Panzer in Turmstellung. Rechts ist die Mulde eines eingefallenen Schützenlochs einer Bereitschaftsstellung zu erkennen. Blick von Osten. Foto J. Musil.

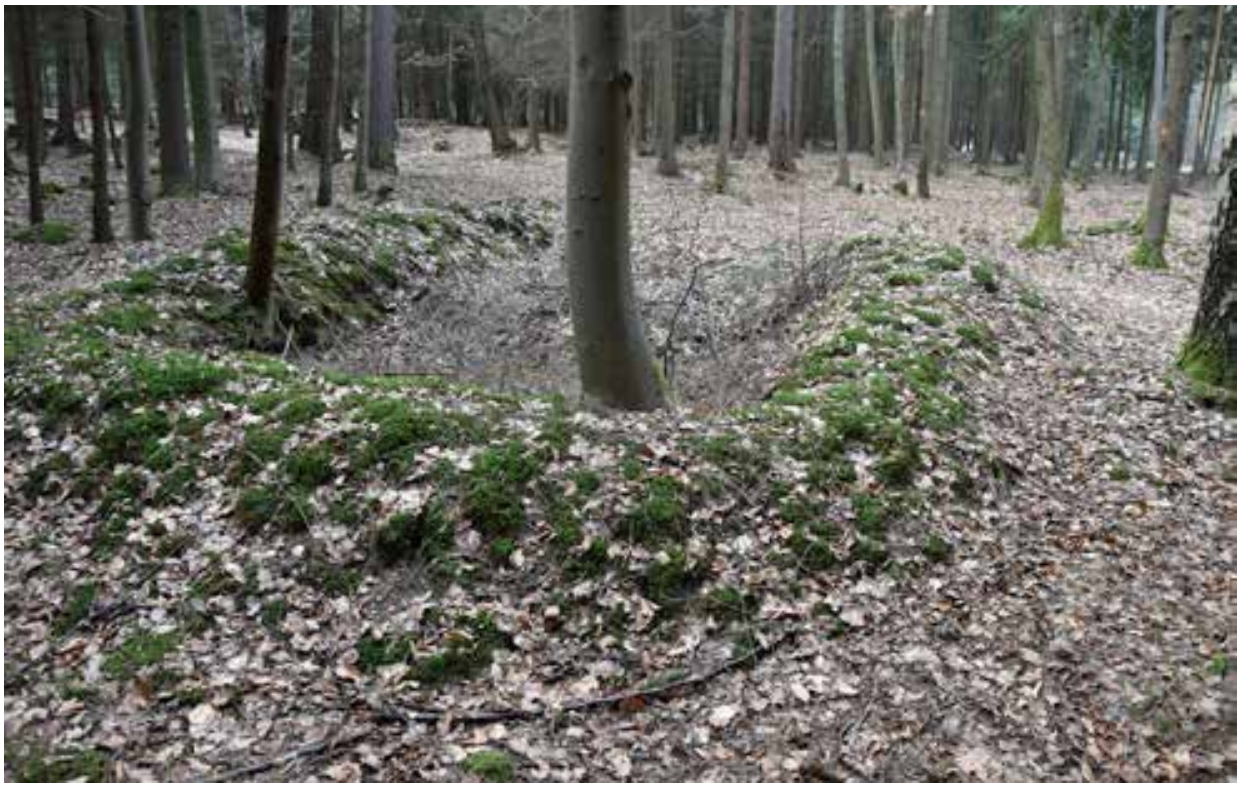

Obr. 5. Dachovské Paseky - Majlant, k. ú. Dachov, okr. Chrudim. Obj. 26 - okop pro OT. Pohled od severu. V přímém sousedství se nalézá obj. 27, rovněž okop pro OT. Foto J. Musil.

Abb. 5. Dachovské Paseky/Dachauer Lichtungen - Majlant, Katastergebiet Dachov/Dachau, Bezirk Chrudim. Objekt 26 Schützengraben für einen gepanzerten Transporter. Blick von Norden. Direkt daneben befindet sich Objekt 27, ebenfalls ein Schützengraben für einen gepanzerten Transporter. Foto J. Musil. 

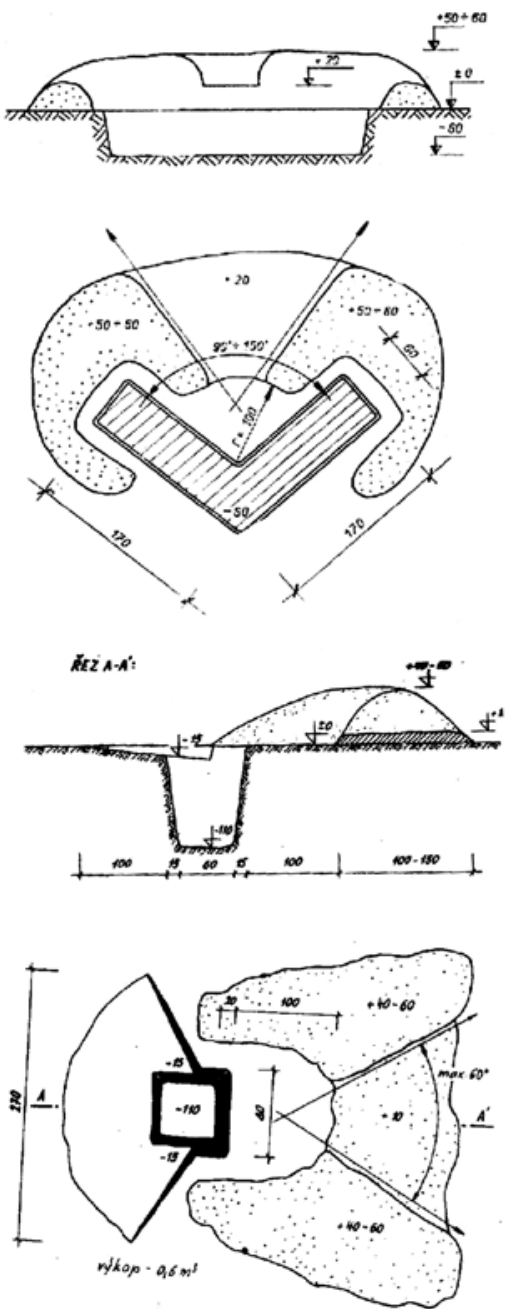

Obr. 6. Vzorové plány okopů podle Žen 2-1/1 a Linha et al. 1971. 1 - okop pro střelbu z kulometu vstoje; 2 - okop pro střelce $\mathrm{z}$ tarasnice/RPG.

Abb. 6. Musterplanskizzen für Schützengräben gemäß der Vorschrift Žen 2-1/1 und Linha et al. 1971. 1 - Schützengraben für Maschinengewehrbeschuss im Stehen; 2 - Schützengraben für Panzerfaust/RPG. transportéry. Dochovaná šiřka objektů kolísá od 3,5 do $5,9 \mathrm{~m}$, dochovaná délka pak od 4,8 do 8,3 m. Pouze ve čtyřech př́ípadech byl u okopu registrován výhoz na čelní straně.

\subsubsection{Okopy pro pěchotu}

V prostoru zkoumané lokality bylo zaznamenáno pouze pět mělkých konkávních objektů (obj. 7-10, 18), které byly ve třech př́ípadech interpretovány jako okop pro střelbu z kulometu vkleče (obr. 6:1; Linha et al. 1971, obr. 7). Charakteristickým znakem okopu pro kulomet je výkop ve tvaru otevřeného písmene $\mathrm{V}$ (obr. 7 a 8 - obj. 9). V jednom případě byl pravděpodobně

11 Tj. spodní šířka okopu činila 3,57 m, spodní délka okopu $6,96 \mathrm{~m}$.

délce vozidla zvětšené o $0,5 \mathrm{~m},{ }^{11}$ hloubka okopu (palebné pláně) se rovnala palné výšce zbraně zmenšené o $0,2-0,3 \mathrm{~m}$ a výšku násypu $(0,4-0,5 \mathrm{~m})$. Délka nájezdové rampy dle podmínek na lokalitě se rovnala 1,5-3 hloubkám okopu. Bylo-li dostatek času a materiálu, byly okopy vybaveny ještě krytem (pod tankem) pro posádku (v suché hornině) či pohotovostním (odpočinkovým) úkrytem $\mathrm{v}$ boční stěně okopu. Na lokalitě bylo zjištěno celkem osm tankových okopů v různém stavu dochování (obj. 2-4, 17, 22-25; obr. 4, obj. 25). Současná délka dochovaných okopů v terénu se pohybuje od 6,5 do $9,8 \mathrm{~m}$ a šírka od $3,8 \mathrm{~m}$ do $6,6 \mathrm{~m}$. Charakteristickým rysem okopu pro tank jsou výhozy zeminy po stranách a zejména na počátku okopu. Pouze v jednom př́ípadě výhoz zcela chyběl (obj. 3). Dalším charakteristickým rysem okopu jsou stopy po pohotovostním úkrytu umístěné vždy po pravé straně (v československých předpisech je zakreslen na levé straně - srov. obr. 3:1; Linha et al. 1971; Žen 2-1/1, obr. 50).

\subsubsection{Okopy pro obrněné transportéry \\ Další skupinu objektů představovaly oko-} py pro obrněné transportéry typů BRMD-1, BRDM-2 či BMP-1 (obr. 3:2). Budovaly se obdobným způsobem jako okopy pro tank ve věžovém postavení tak, aby bylo možno užívat palubní zbraně (zejm. velkorážný kulomet). Od okopů pro tanky se liší jednak rozměry a dále absencí pohotovostního úkrytu v boční stěně. Vzhledem k silnému narušení objektů nelze na základě dochovaných rozměrů jednoznačně tyto objekty ztotožnit s konkrétním typem obrněného transportéru (srov. Žen 2-1/1, tab. 7 a 10; Linha et al. 1971, tab. 2). Celkem bylo dokumentováno 20 objektů (obj. $1,5,6,11-13,15,16,19-21,26-31,33,34,36$; obr. 5, obj. 26), které lze s určitou mírou pravděpodobnosti ztotožnit s okopy pro obrněné 


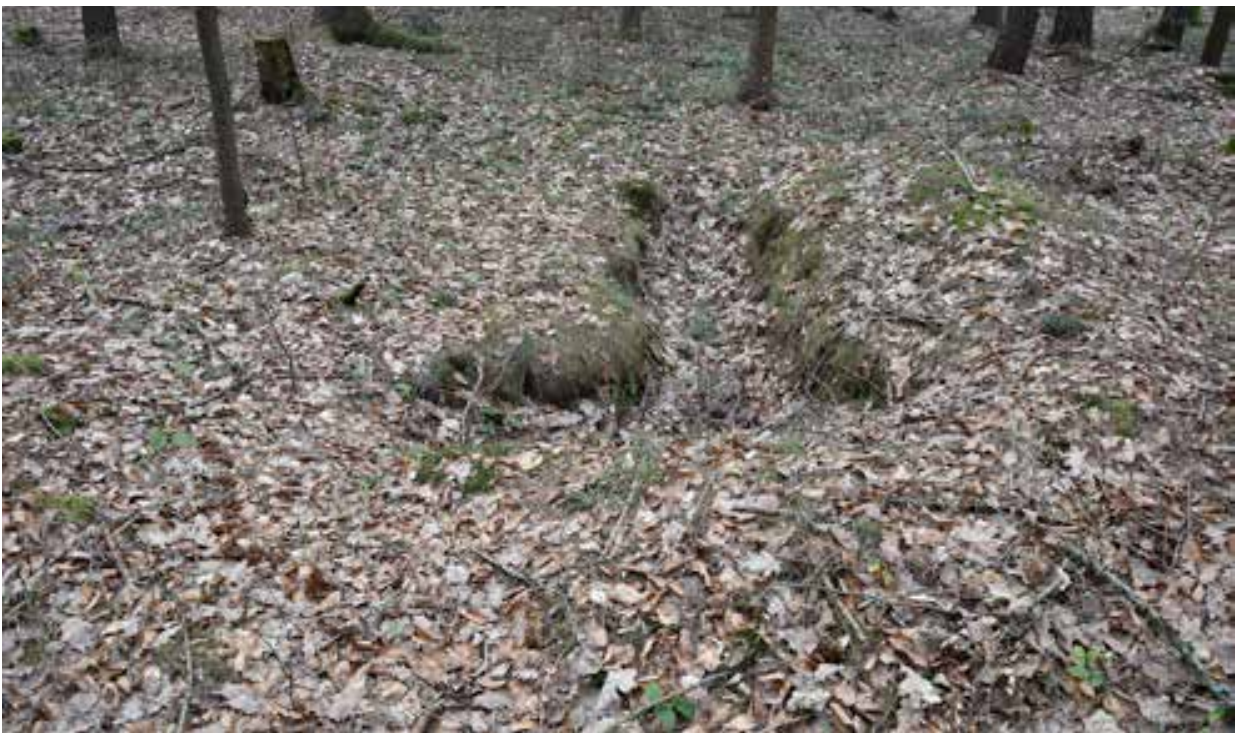

Obr. 7. Dachovské Paseky - Majlant, k. ú. Dachov, okr. Chrudim. Obj. 9 - okop pro stř̌elbu z kulometu vstoje. Pohled od severu. Foto J. Musil.

Abb. 7. Dachovské Paseky/Dachauer Lichtungen - Majlant, Katastergebiet Dachov/Dachau, Bezirk Chrudim. Objekt 9 Schützengraben für Maschinengewehrbeschuss im Stehen. Blick von Norden. Foto J. Musil.

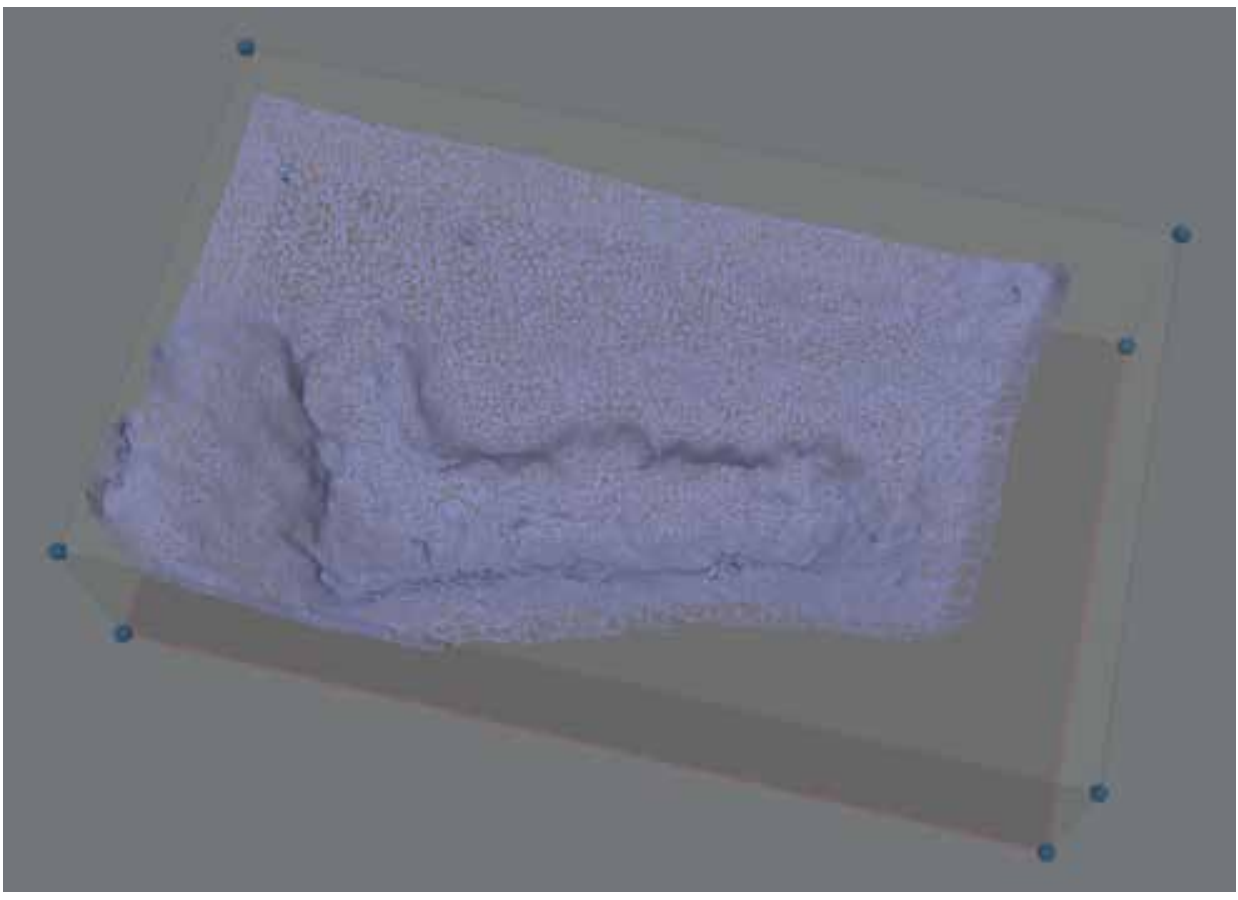

Obr. 8. Dachovské Paseky - Majlant, k. ú. Dachov, okr. Chrudim. 3D model obj. 9 - okopu pro střelbu z kulometu vstoje. Abb. 8. Dachovské Paseky/Dachauer Lichtungen - Majlant, Katastergebiet Dachov/Dachau, Bezirk Chrudim. 3D-Modell von Objekt 9 - Schützengraben für Maschinengewehrbeschuss im Stehen. 
identifikován okop pro střelbu z tarasnice či RPG vstoje o téměř kruhovém tvaru 4,6 × 4,2 m a dochované hloubce $0,5 \mathrm{~m}$ (obr. 6:2, srov. Žen 2-1/1, obr. 30b; Linha et al. 1971, obr. 8). V celém zkoumaném prostoru byl identifikován pouze jeden okop pro ležícího střelce (obr. 9; srov. Žen 2-1/1, obr. 23; Linha et al. 1971, obr. 1) o maximální délce $3 \mathrm{~m}$ a šířce $1 \mathrm{~m}$. Současná hloubka okopu je $0,3 \mathrm{~m}$. Vzhledem k jeho rozměrům je zjevné, že tyto objekty zanikaly nejdříve.

\section{Závěr}

Vojenské polní opevňovací objekty vzniklé po roce 1945 nelze přímo datovat bez provedení sondáže, avšak na základě výše zjištěných výsledků nedestruktivního archeologického výzkumu a rešerší historických pramenů lze přiřadit vznik objektů v trati U Salvátora (k. ú.

\section{FA'ZE BUDOVIN':}

\section{REZ A-A':}

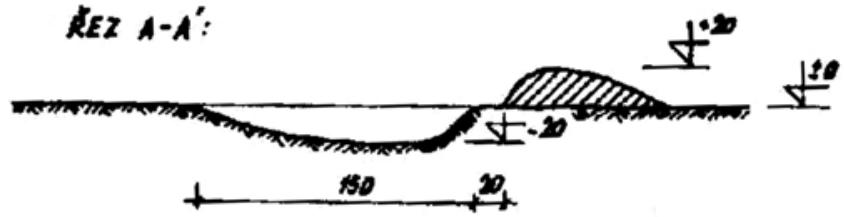

$$
\text { vykop }-0,16 m^{2}
$$

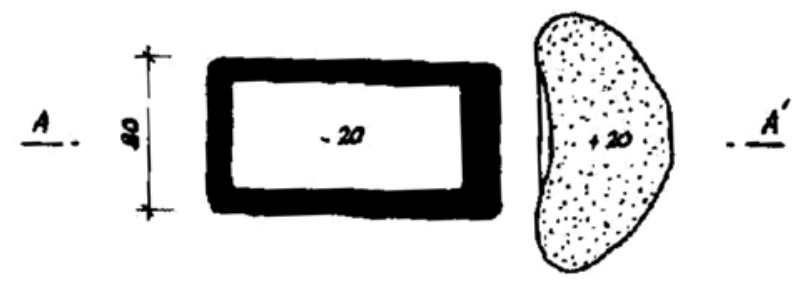

\section{PO DOKONCEN":}
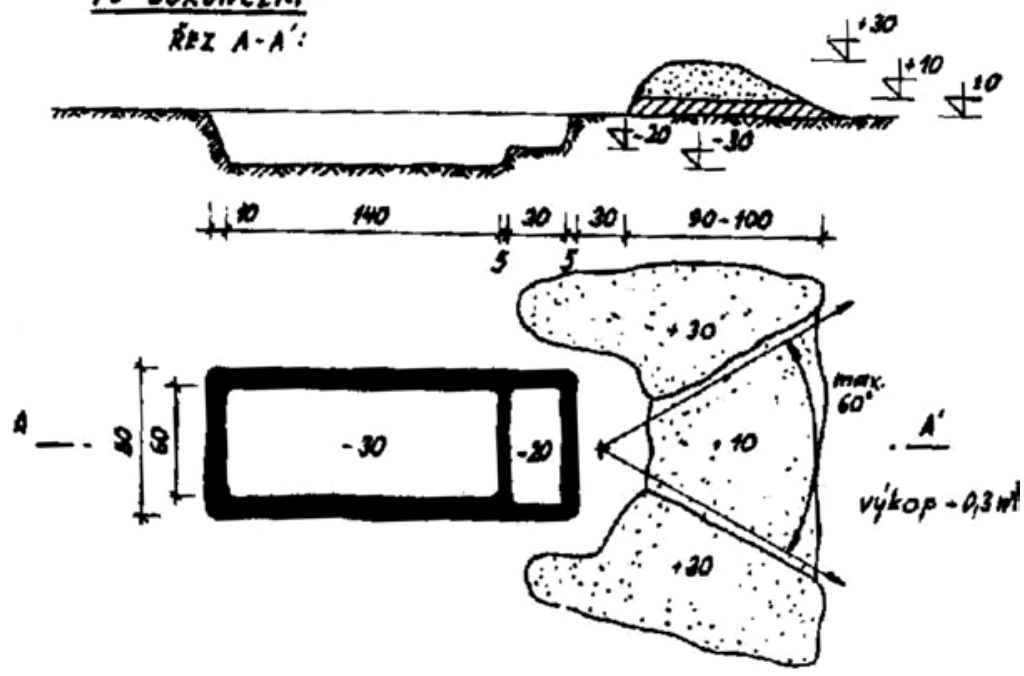

Obr. 9. Vzorové plány okopů pro ležícího střelce podle Žen 2-1/1.

Abb. 9. Musterplanskizze für einen liegenden Schützen gemäß der Vorschrift Žen 2-1/1. 
Dachov) k událostem spojeným se vpádem okupačních vojsk v srpnu roku 1968. Podle svědectví místních pamětníků docházelo $\mathrm{k}$ dalším úpravám a využívání objektů i v průběhu následujících let v rámci vojenských cvičení. Míru pozdější adaptace však nejsme schopni bez destruktivního archeologického výzkumu určit.

Jednotlivé antropogenní terénní pozůstatky vojenských objektů se dochovaly v relativně velmi dobrém stavu. K intenzivnějšímu narušování a zániku objektů dochází patrně až v průběhu posledních dvou desetiletí. Zejména větší okopy pro tanky a obrněné transportéry jsou průběžně místními obyvateli zaváženy stavební sutí a organickým odpadem. Dále jsou tyto objekty zasypávány a nivelizovány při úpravě lesních cest (např. obj. 22-24). Všechny objekty jsou pak poškozovány i nelegálními zásahy skupin s detektory kovů. Poměrně nízké zastoupení okopů pro pěchotu je dáno menšími rozměry a s tím souvisejícím rychlejším postupem archeologizace objektu. Proto je nelze tak jednoznačně v terénu identifikovat. Jak vyplynulo z analýzy písemných pramenů, svědectví místních pamětníků a prováděného nedestruktivního archeologického výzkumu, na území okresu Chrudim registrujeme celkem 14 ležení z období srpnové invaze vojsk Varšavské smlouvy v roce 1968 (obr. 1). Předložený příspěvek prezentuje zatím první terénní archeologický výzkum zaměřený na hmotné pozůstatky vojenské činnosti zahraničních vojsk v období po druhé světové válce na území východních Čech. Konkrétně se jedná o vojenské ležení př́islušníků 10. tankové divize 2. armády PLA, která do východních Čech postupovala z nástupního prostoru Plisz.

Článek vznikl s podporou studentské grantové soutěže FF ZČU SGS-2016-053 „Hospodářské zázemí a př́irodní prostředí zaniklých středověkých a novověkých vesnických sídel - 2. etapa“.

\section{Zkratky}

BLA - Bulharská lidová armáda

BLR - Bulharská lidová republika

ČSLA - Československá lidová armáda

ČSSR - Československá socialistická republika

MěNV - Městský národní výbor

MLR - Mad’arská lidová republika

NDR - Německá demokratická republika

NLA - Národní lidová armáda NDR

OT - obrněný transportér

PLA - Polská lidová armáda

PLR - Polská lidová republika

SA - Sovětská armáda

SNB - Sbor národní bezpečnosti

SSSR - Svaz sovětských socialistických republik

\section{Prameny a literatura}

BENČÍK, A., 1994: Operace „Dunaj“. Vojáci a Pražské jaro 1968. Praha.

- 1998: Rekviem za Pražské jaro. Třebíč.

BENČíK, A.-NAVRÁTIL, J.-PAULÍK, J., 1996: Vojenské otázky československé reformy 1967-1970. Vojenská varianta řešení čs. krize (1967-1968). I. díl. Brno.

BLAŽEK, P., ed., 2006: Polsko a Československo v roce 1968. Praha.

DURMAN, K., 1998: Útěk od praporů. Kreml a krize impéria 1964-1991. Praha.

EMMERT, F., 2007: Rok 1968 v Československu. Praha.

ФЕСЬКОВ, В. И.-КАЛАШНИКОВ, К. А.-ГОЛИКОВ, В. И., 2004: Советская Армия в годы «холодной войны» (1945-1991). Томск. 
HAVLÍČEK, D., 1998: Jaro na krku. Zážitky ze zákulisí sekretariátu ÚV KSČ od června do prosince 1968. Praha.

FUNK, L.-VÁŇA, M., 2012: Datování objektů zaniklých po roce 1945 pomocí dendrochronologie živých stromů - Die Datierung von nach 1945 aufgegebenen Objekten mithilfe der Dendrochronologie lebender Bäume, AH 37, 799-807.

HEROLD, J.-LENDEROVÁ, M.-SVATOŇOVÁ, S.-ZIMMERMANN, P., 1990: Jaro, invaze a normalizace na Královéhradecku. Sborník dokumentů z let 1968-1970. Hradec Králové.

HORÁK, V.-NOVOTNÍK, J., 2004: Vojáci, kteří neztratili svou čest. Sborník vzpomínek československých vojáků na srpen 1968 a následné normalizace československé armády. II. díl. Praha.

CHRASTIL, S.-NOVOTNÍK, J., 2002: Vojáci, kteří neztratili svou čest. Sborník vzpomínek československých vojáků na srpen 1968 a následné normalizace československé armády. I. díl. Praha.

KINZLOVÁ, I., 2012: Hradec Králové v srpnu 1968 (21. 8. - 31. 8. 1968). Nepublikovaná bakalářská práce, Historický ústav FF MU.

KOBETIČ, P., 1990: Srpen 1968 očima kronikáře. Materiály muzeí chrudimského okresu, řada „K“, č. 9. Chrudim.

KRONIKA MĚSTA HLINSKA 1968: Státní okresní archiv v Chrudimi, fond Městský národní výbor Hlinsko (1945-1990). Svazek 4.

KRONIKA OBCE PROSEČE 1968: Státní okresní archiv v Chrudimi, fond Místní národní výbor Proseč 1945-1990. Kroniky Proseče II. Místní části Podměstí, Záboří. Svazek 6.

KURLANSKY, M., 2007: 1968. Rok, který otřásl světem. Praha.

КАЛИБЕРНОВ, Е. С.-КОРНЕВ, В. И.-СОСКОВ, А. А. 1984: Инженерное обеспечение боя. Москва.

KRONIKA 1966-1982: Státní okresní archiv v Chrudimi, fond Městský národní výbor Chrast (1945-1990), Město Chrast. Kronika za léta 1966-1980. Svazek 4. Díl IIB. Sepsaná 1997-1998.

LINHA, M. et al., 1971: Př́ručka pro poddůstojníky. Praha.

МАИОРОВ, А., 1998: Вморжение. Чэхословакия 1968. Mockba.

MORRIS, R., 2003: The Archaeology of Conflict - Introduction, Conservation bulletin, Issue 44, 2-3.

MUSIL, J.-NETOLICKÝ, P., 2014: Současný stav a perspektivy výzkumu antropogenních pozůstatků sídelních, výrobních a těžebních areálů v prostoru Železných hor, AVJČ 5/2013, 227-239.

MUSIL, J.-NETOLICKÝ, P.-VAŘEKA, P., 2016: Archeologické relikty ústředí partyzánské brigády Mistra Jana Husa v areálu stř̌edověkého rýžoviště zlata (k. ú. Zbyslavec, okr. Chrudim), Východočeský sborník historický 29, 189-207.

PAJÓREK, Ł., 1996: Účast polské armády na operaci DUNAJ, Historie a vojenství 45, č. 1, 66-86.

- 1998: Połska a „Praska wiosna“. Udział Wojska Połskiego w interwencji zbrojnej w Czechosłowacji w 1968 roku. Warszawa.

PAMĚTNÍ KNIHA MĚSTA SKUTČE 1967-1970: Státní okresní archiv v Chrudimi, fond Místní národní výbor Skuteč, inv. č. 131.

PAUER, J., 2004: Praha 1968. Vpád Varšavské smlouvy. Pozadí - plánování - provedení. Praha.

PAZDERKA, J., ed., 2011: Invaze 1968. Ruský pohled. Praha.

PECKA, J. et al., 1996: Sovětská armáda v Československu 1968-1991. Praha.

POVOLNÝ, D., 2008: Vojenské řešení Pražského jara. I. Invaze armád Varšavské smlouvy. Praha.

RAK, M., 2013: Archeologie konfliktů 20. století. In: Archeologie 19. a 20. století. Př́stupy - Metody - Témata (Vařeka, P., ed.), 115-136. Plzeň.

RAK, M.-STARKOVÁ, L.-FUNK, L., 2014: Relikty „Studené války“ jako součást kulturní historie, Veřejná archeologie 5, 42-61.

РУКОВОДСТВО 1962: Руководство по войсковым фортификационным сооружениям. Военное издательство Министерства обороны СССР. Москва.

СБОРНИК 1970: Сборник нормативов по инженерному обеспечению боевых действий войск. Военное издательство. Москва.

SCHOFIELD, J., 2003: Military archaeology, Past practice - future directions, Conservation bulletin, Issue $44,4-7$.

- 2005: Combat Archaeology. Material Culture and Modern Conflict. London.

VÁŇA, M., 2016: Datování objektů na lokalitě Majlant metodou dendrochronologie živých stromů (průvodní zpráva), ulož. v Regionálním muzeu v Chrudimi.

VAŘEKA, P., 2009: Dokumentace reliéfních antropogenních tvarů. In: Vařeka, P. a kol., Archeologie zaniklých středověkých vesnic na Rokycansku I, 57-60. Plzeň.

VAŘEKA, P., ed., 2013: Archeologie 19. a 20. století. Př́ístupy - Metody - Témata. Plzeň.

WENZKE, R., 1995: Die NVA und der Prager Frühling 1968. Die Rolle Ulbrichts und der DDR-Streitkräfte bei der Niederschlagung der tschechoslowakischen Reform. Berlin. 
WILLIAMS, K., 1997: The Prague Spring and its aftermath. Czechoslovak politics 1968-1970. London. ŽEN 2-1/1: Polní opevňování (Povrchové a zapuštěné objekty). Předpis Ministerstva obrany ČSSR značka Žen (Ženijní vojsko, zabezpečení, činnosti) 2-1/1. Praha 1972.

\section{Zusammenfassung}

\section{Feldbefestigungsobjekte aus dem Jahr 1968 in der Region Chrudim}

Die Gegliedertheit und Vielfalt des Geländes im südlichen Teil des Bezirks Chrudim (Ostböhmen, Landkreis Pardubice) machte es bis heute unmöglich, eine landwirtschaftliche Tätigkeit zu entwickeln, weswegen die Forstwirtschaft in dieser Region verhältnismäßig dominant ist. Die relativ dichte Bewaldung des betreffenden Gebietes hat ab dem Mittelalter bis in die jüngste Vergangenheit direkt im Gelände eine Reihe anthropogener Relikte von Siedlungs-, Produktions- und Abbauaktivitäten konserviert. Eine spezielle Stellung nehmen hier sehr schnell untergehende Objekte aus der jüngsten Vergangenheit ein, denen aus Sicht des Denkmalschutzes fast keinerlei Aufmerksamkeit entgegengebracht wurde. Ein Teil dieser Objekte wird im Rahmen der Archäologie der Moderne untersucht. Im vorliegenden Beitrag präsentieren wir die Ergebnisse einer zerstörungsfreien archäologischen Untersuchung, welche auf die Gewinnung von Erkenntnissen über das Feldbefestigungssystem ausgerichtet ist, das aus der Zeit der Okkupation durch die Armeen des Warschauer Paktes, d.h. im August bis Dezember 1968, in den Wäldern bei der Dorfgemeinde Majlant (Katastergebiet Dachov) in der Region Chrudim erhalten geblieben ist. Insgesamt wurde 36 anthropogene Reliefrelikte identifiziert und geodätisch vermessen, die mit Gewissheit als Relikte von Feldbefestigungsrelikten (Abb. 2) identifiziert werden können. Der eigentlich rechteckige Kern des geschlossenen Militärlagers hat die Abmessungen von ungefähr $150 \times 250 \mathrm{~m}$. Entlang der Waldwege außerhalb dieses Rechtecks befanden sich noch weitere Befestigungsobjekte des Militärkontingents. Insgesamt erstreckten sich die Militärobjekte über eine ungefähr 1,2 m große Fläche. Alle Objekte sind von den Waldwegen her zugänglich. Entdeckt wurden Schützengräben für die Infanterie und schwere Technik (Panzer, gepanzerte Transporter).

Der vorliegende Beitrag entstand im Rahmen des Studentenförderwettbewerbs der Philosophischen Fakultät der Westböhmischen Universität SGS-2016-053 „Das wirtschaftliche Hinterland und die Umwelt von mittelalterlichen und neuzeitlichen Dorfsiedlungswüstungen - 2. Etappe“.

PhDr. Jan Musil, Regionální muzeum v Chrudimi, Široká 86, 53701 Chrudim, Katedra archeologie Filozofické fakulty Západočeské univerzity v Plzni, Sedláčkova 15, 30614 Plzeň, Česká republika, musil@muzeumcr.cz

Mgr. Petr Netolický, Katedra archeologie Filozofické fakulty Západočeské univerzity v Plzni, Sedláčkova 15, 30614 Plzeň, Česká republika, netolicky.petr@seznam.cz 
